\title{
Advances in Understanding and Managing Chronic Urticaria
}

\section{[version 1; peer review: 2 approved]}

\author{
Yasmin Moolani ${ }^{1}$, Charles Lynde2,3, Gordon Sussman ${ }^{1,4}$ \\ ${ }^{1}$ Division of Clinical Immunology and Allergy, University of Toronto, Toronto, $\mathrm{OH}$, Canada \\ ${ }^{2}$ Division of Dermatology, University of Toronto, Toronto, ON, Canada \\ ${ }^{3}$ Lynderm Research, Lynde Institute for Dermatology, Markham, ON, Canada \\ ${ }^{4}$ Gordon Sussman Clinical Research Inc, GSCR, Toronto, ON, Canada
}

V1 First published: 16 Feb 2016, 5(F1000 Faculty Rev):177

https://doi.org/10.12688/f1000research.7246.1

Latest published: 16 Feb 2016, 5(F1000 Faculty Rev):177

https://doi.org/10.12688/f1000research.7246.1

\section{Abstract}

There have been recent advances in the classification and management of chronic urticaria. The new term chronic spontaneous urticaria (CSU) has replaced chronic idiopathic urticaria and chronic autoimmune urticaria. In addition, chronic inducible urticaria (CINDU) has replaced physical urticaria and includes other forms of inducible urticaria, such as cholinergic and aquagenic urticaria. Furthermore, novel research has resulted in a new understanding with guidelines being revised in the past year by both the American Academy of Allergy, Asthma, and Immunology (AAAAI) and the European Academy of Allergy and Clinical Immunology (EAACI)/Global Allergy and Asthma European Network (GA2LEN)/European Dermatology Forum (EDF)/World Allergy Organization (WAO). There are some differences in the recommendations, which will be discussed, but the core updates are common to both groups. The basic treatment for chronic urticaria involves second-generation non-sedating non-impairing $\mathrm{H}_{1}$ antihistamines as first-line treatment. This is followed by up to a 4 -fold increase in the licensed dose of these $\mathrm{H}_{1}$ antihistamines. The major therapeutic advance in recent years has been in third-line treatment with omalizumab, a humanized monoclonal anti-immunoglobulin $\mathrm{E}$ (anti-IgE) antibody that prevents binding of IgE to the high-affinity IgE receptor. Several multicenter randomized controlled trials have shown safety and efficacy of omalizumab for CSU. There are also some small studies showing efficacy of omalizumab in CINDU. While there were previously many treatment options which were lacking in strong evidence, we are moving into an era where the treatment algorithm for chronic urticaria is simplified and contains more evidence-based, effective, and less toxic treatment options.

\section{Keywords}

Chronic Urticaria, Classification, Management , Antihistamines, Updosing, Omalizumab

\author{
Open Peer Review \\ Approval Status \\ 1 \\ version 1 \\ 16 Feb 2016 \\ Faculty Reviews are review articles written by the \\ prestigious Members of Faculty Opinions. The \\ articles are commissioned and peer reviewed \\ before publication to ensure that the final, \\ published version is comprehensive and \\ accessible. The reviewers who approved the final \\ version are listed with their names and \\ affiliations. \\ 1. Richard Warrington, University of Manitoba, \\ Winnipeg, Canada \\ 2. Riccardo Asero (iD), Clinica San Carlo, Milan, \\ Italy \\ Any comments on the article can be found at the \\ end of the article.
}


Corresponding author: Gordon Sussman (gsussman@rogers.com)

Competing interests: Gordon Sussman is a consultant, speaker, and researcher for Novartis pharmaceuticals. He is also an advisor for CSL Behring and Merck and does research for DBV Technologies, Merck, and AstraZeneca.

Grant information: The author(s) declared that no grants were involved in supporting this work.

Copyright: @ 2016 Moolani $Y$ et al. This is an open access article distributed under the terms of the Creative Commons Attribution License, which permits unrestricted use, distribution, and reproduction in any medium, provided the original work is properly cited.

How to cite this article: Moolani Y, Lynde C and Sussman G. Advances in Understanding and Managing Chronic Urticaria [version 1; peer review: 2 approved] F1000Research 2016, 5(F1000 Faculty Rev):177 https://doi.org/10.12688/f1000research.7246.1

First published: 16 Feb 2016, 5(F1000 Faculty Rev):177 https://doi.org/10.12688/f1000research.7246.1 


\section{Introduction}

Urticaria (hives) is a relatively common condition, with a point prevalence of about $0.5-1 \%$. The peak incidence is in the range of 20-40 years. Urticaria is the general term for a cutaneous response characterized by wheals and swellings. A deeper localized swelling often associated with urticaria is called angioedema. Urticaria is mediated by mast cell degranulation. Mast cells can be activated by immunologic and non-immunologic mechanisms, which lead to degranulation of inflammatory mediators including histamine, leukotrienes, and prostaglandins. Release of these mediators causes the characteristic pruritus, vascular permeability, and edema.

\section{Classification}

Acute urticaria is defined as hives that last less than 6 weeks, while chronic urticaria refers to urticaria that occurs intermittently for at least 6 weeks, typically on most days of the week. Acute urticaria can occur spontaneously or in response to a trigger. Triggers of acute urticaria are typically acute viral infections or allergic reactions to foods, medications, latex, or insects. Chronic urticaria can also be spontaneous or inducible, though the triggers of inducible urticaria are different compared to those of acute urticaria. Inducible urticaria involves hiving responses resulting from physical stimuli including scratch (dermographism) and cold contact urticaria. Additional triggers of chronic urticaria include pressure, temperature change, sun exposure, water exposure, and exercise (Figure 1, Table 1) ${ }^{2-5}$.

\section{New terminology}

While the pathogenesis of urticaria remains incompletely understood, our knowledge of the etiology of chronic urticaria has increased. We are able to differentiate the older terminology of chronic autoimmune urticaria or chronic idiopathic urticaria from physically induced urticaria ${ }^{6}$. However, now physical urticaria has been revised to chronic inducible urticaria (CINDU) to reflect the external trigger and inducible nature. The term CINDU also includes cholinergic, aquagenic, and contact urticaria. The remaining forms of urticaria, which occur without an external trigger and instead via an endogenous mechanism, are classified as chronic spontaneous urticaria (CSU). This is simplified and more specific than the term chronic idiopathic urticaria, which is now falling out of use $^{2}$ (Figure 1).

\section{Assessing disease severity and impact on quality of life}

The primary symptom of urticaria is pruritus. Urticaria generally causes significant disability adversely affecting an individual's life. New tools have been developed to quantify the effect of urticaria on quality of life. One such tool is the Urticaria Activity Score (UAS7), which is a validated score recommended by urticaria guidelines ${ }^{7}$. In the UAS7, the patient records the severity of itching and the number of wheals daily for 7 days. A score of $<7$ in 1 week indicates control of disease, whereas a score of $>28$ per week indicates severe

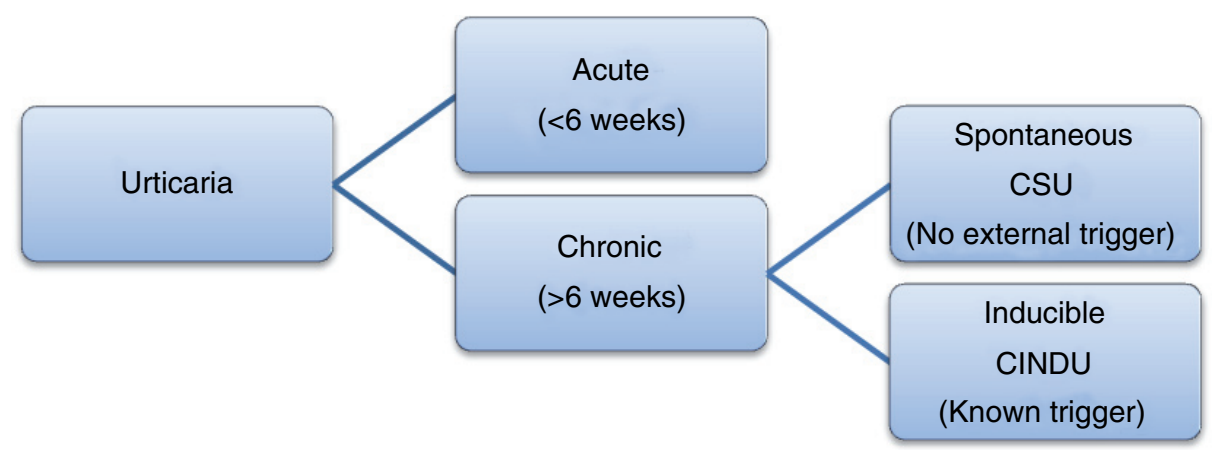

Figure 1. Classification of Urticaria. The revised classification of urticaria divides chronic urticaria into chronic spontaneous urticaria (CSU), with no external trigger, and chronic inducible urticaria (CINDU), with an identifiable trigger. Acute urticaria remains as that which lasts less than 6 weeks.

Table 1. Triggers of Acute Urticaria and Chronic Inducible

Urticaria. The triggers of acute and chronic urticaria are different and are outlined in this table.

\begin{tabular}{|l|l|l|}
\hline Classification & $\begin{array}{l}\text { Acute Urticaria } \\
\text { (<6 weeks) }\end{array}$ & $\begin{array}{l}\text { Chronic Inducible Urticaria } \\
\text { (>6 weeks) }\end{array}$ \\
\hline & Infection & Dermographism \\
\hline \multirow{5}{*}{ Triggers } & Food & Cholinergic \\
\hline & Medication & Cold-induced \\
\hline & Venom & Solar \\
\hline & Latex & Aquagenic \\
\hline Contact & Vibration \\
\hline & Idiopathic & Delayed-pressure \\
\hline
\end{tabular}


disease. This tool allows for efficient clinical practice, maximizing the information gathered during patient visits while minimizing the use of resources and time. While the UAS7 is a prospective tool, a retrospective tool was also developed, the Urticaria Control Test $(\mathrm{UCT})^{8}$. Additional questionnaires have been developed and are recommended for use to assess the impact of urticaria on quality of life. The recently developed tools include the Chronic Urticaria Quality of Life Questionnaire (CU-Q2oL) ${ }^{9}$ and the Urticaria Severity Score $^{10}$. These tools were designed specifically for urticaria since other more generic questionnaires do not capture the nuances of the impact of urticaria on one's quality of life (Table 2).

\section{Advances in management}

Recently, new guidelines have been published by the American Academy of Allergy, Asthma, and Immunology (AAAAI) and the European Academy of Allergy and Clinical Immunology (EAACI)/ Global Allergy and Asthma European Network (GA²LEN)/European Dermatology Forum (EDF)/World Allergy Organization (WAO) that update what is currently understood about urticaria ${ }^{3-5}$. There are several other published regional guidelines with similar recommendations, including Canadian ${ }^{11}$. With the exception of the American guidelines, the other organizations put forth a similar algorithm. That is, the following stepwise approach: first-line treatment includes second-generation $\mathrm{H}_{1}$ antihistamines, second-line therapy involves up-dosing the second-generation $\mathrm{H}_{1}$ antihistamine, and third-line treatment includes a new medication, omalizumab, which we recommend to be used before a more toxic medication, cyclosporine A.

One of the notable differences in the guidelines put forth by the American versus European/World guidelines is the role for firstgeneration $\mathrm{H}_{1}$ antihistamines. The AAAAI keeps first-generation $\mathrm{H}_{1}$ antihistamines in the treatment algorithm. The EAACI/GA ${ }^{2} \mathrm{LEN} /$ EDF/WAO guidelines specifically recommend avoiding firstgeneration $\mathrm{H}_{1}$ antihistamines based on the benefit-to-risk ratio of these agents. The known risks are cited as well as the high underestimated risk potential when these agents are taken in the evening, such as changes in REM sleep patterns and impairment of cognitive functions $^{12}$. For similar reasons, the EAACI/GA²LEN/EDF/WAO guidelines do not address a role for hydroxyzine or doxepin, whereas the AAAAI guidelines include these medications as options if up-dosing of non-sedating, non-impairing $\mathrm{H}_{1}$ antihistamines is not successful at complete control of symptoms.

The EAACI/GA²LEN/EDF/WAO guidelines do not include $\mathrm{H}_{2}$ antihistamines in their algorithm due to a recent Cochrane review that shows lack of evidence of efficacy of these medications ${ }^{13}$. Thus, $\mathrm{H}_{2}$ antihistamines are advised only on an individual case basis but not as first-, second- or third-line treatment. The AAAAI guidelines, however, consider the options of up-dosing second-generation $\mathrm{H}_{1}$ antihistamines, adding other second-generation $\mathrm{H}_{1}$ antihistamines, and adding $\mathrm{H}_{2}$ antagonists, leukotriene receptor antagonists or firstgeneration $\mathrm{H}_{1}$ antihistamines at bedtime to all be equally weighted second-line options ${ }^{3}$. In doing this, however, the adverse reaction profile would increase.

Both guidelines recommend that corticosteroids should be considered only for the short-term intervention and avoided as long-term treatments due to the significant number of side effects and alternative options for treatment. Both guidelines also acknowledge a role for cyclosporine A as an add-on treatment for patients who have refractory chronic urticaria that is not responsive to the above mentioned treatments $\mathrm{s}^{3,5}$.

Both guidelines have also incorporated a new third-line treatment option, omalizumab, a subcutaneously injected, biologic medication ${ }^{3,5}$. There is a large body of new data showing efficacy of omalizumab in various subtypes of chronic urticaria with a relatively low level of adverse effects ${ }^{18-24}$. Omalizumab is a recombinant humanized immunioglobulin G1 ( $\operatorname{IgG} 1$ ) monoclonal antibody that binds to $\mathrm{IgE}$. In binding $\mathrm{IgE}$, omalizumab inhibits binding of $\mathrm{IgE}$ to the high-affinity IgE receptor (FceRI) found on the surface of mast cells and basophils. By inhibiting binding of $\operatorname{IgE}$ to the receptor, the release of inflammatory mediators such as histamine, leukotrienes, and prostaglandins is limited, thus blunting the inflammatory response ${ }^{14}$. By inhibiting IgE from binding the FceRI receptor,

Table 2. Tools to assess the impact of chronic urticaria on quality of life. There are a number of recently developed tools specifically for urticaria to assess severity and impact on quality of life.

\begin{tabular}{|l|l|}
\hline Tool & Description \\
\hline Urticaria Activity Score (UAS7) & $\begin{array}{l}\text { Prospective tool, patients record severity of itch and } \\
\text { number of wheals daily, must be recorded by patient } \\
\text { for } 7 \text { consecutive days, assesses disease activity }\end{array}$ \\
\hline Urticaria Control Test (UCT) & $\begin{array}{l}\text { Retrospective tool, four-item questionnaire to } \\
\text { determine control of disease }\end{array}$ \\
\hline $\begin{array}{l}\text { Chronic Urticaria Quality of Life } \\
\text { Questionnaire (CU-Q2oL) }\end{array}$ & $\begin{array}{l}\text { Retrospective tool, 23-item questionnaire, assesses } \\
\text { quality of life }\end{array}$ \\
\hline Urticaria Severity Score (USS) & $\begin{array}{l}\text { Instrument for monitoring severity, } 12 \text { questions } \\
\text { I0 }\end{array}$ \\
\hline
\end{tabular}


omalizumab also has the effect of down-regulating the FceRI receptor on the surface of mast cells and basophils. This monoclonal antibody has also been shown to decrease the release of circulating interleukin- 6 and tumor necrosis factor $\alpha$ and to decrease the recruitment of T cells, eosinophils, and macrophages in the inflammatory response ${ }^{15}$. The overall effect of omalizumab is to prevent urticaria and angioedema ${ }^{14}$.

Omalizumab was approved in Europe and North America in 2014 for the treatment of CSU in adults and adolescents 12 years of age and older who do not respond to $\mathrm{H}_{1}$ antihistamines ${ }^{16,17}$. This approval was based on three phase III randomized clinical trials evaluating over 1000 patients' treatment response with inadequately controlled $\mathrm{CSU}^{18-20}$. There have also been several published real life trials demonstrating efficacy and safety ${ }^{21-23}$. Additionally, there are smaller case studies assessing the efficacy of omalizumab in various subtypes of CINDU, and while the number of overall cases is low, all have shown notable improvement in urticaria symptoms ${ }^{24}$. Future research is, therefore, required to evaluate the role of omalizumab in the various subtypes of chronic urticaria as well as to establish standardized protocols for dosing and monitoring adverse effects of long-term therapy.

\section{Conclusion}

A number of notable changes have occurred recently in the guidelines for managing chronic urticaria. Overall, the classification and management have become more simplified. There are new tools to track and monitor the quality of life of patients with this challenging disease. Furthermore, the recent addition of omalizumab to the treatment algorithm for CSU has offered a more effective and less toxic treatment option to those suffering with refractory disease to older treatment strategies. With the many trials currently underway for CINDU, the outlook is optimistic.

\section{Competing interests}

Gordon Sussman is a consultant, speaker, and researcher for Novartis pharmaceuticals. He is also an advisor for CSL Behring and Merck and does research for DBV Technologies, Merck, and AstraZeneca.

\section{Grant information}

The author(s) declared that no grants were involved in supporting this work.
1. $\mathrm{F}$ Maurer M, Weller $\mathrm{K}$, Bindslev-Jensen $\mathrm{C}$, et al:: Unmet clinical needs in chronic spontaneous urticaria. A GA2LEN task force report. Allergy. 2011; 66(3): 317-330.

PubMed Abstract | Publisher Full Text | F1000 Recommendation

2. Maurer M, Bindslev-Jensen C, Gimenez-Arnau A, et al:: Chronic idiopathic urticaria (CIU) is no longer idiopathic: time for an update. Br J Dermatol. 2013; 168(2): 455-456.

PubMed Abstract | Publisher Full Text

3. F Bernstein JA, Lang DM, Khan DA, et al:: The diagnosis and management of acute and chronic urticaria: 2014 update. J Allergy Clin Immunol. 2014; 133(5): 1270-1277.

PubMed Abstract | Publisher Full Text | F1000 Recommendation

4. Zuberbier T, Aberer W, Asero R, et al:: Methods report on the development of the 2013 revision and update of the EAACI/GA2LEN/EDF/WAO guideline for the definition, classification, diagnosis, and management of urticaria. Allergy. 2014; 69(7): e1-29.

PubMed Abstract | Publisher Full Text

5. Zuberbier T, Aberer W, Asero R, et al:: The EAACI/GA2LEN/EDF/WAO Guideline for the definition, classification, diagnosis, and management of urticaria: the 2013 revision and update. Allergy. 2014; 69(7): 868-887.

PubMed Abstract | Publisher Full Text

6. Kaplan AP: Chronic urticaria: pathogenesis and treatment. J Allergy Clin Immunol. 2004; 114(3): 465-74, quiz 475. PubMed Abstract | Publisher Full Text

7. $\quad F$ Młynek A, Zalewska-Janowska A, Martus $P$, et al:: How to assess disease activity in patients with chronic urticaria? Allergy. 2008; 63(6): 777-780. PubMed Abstract | Publisher Full Text | F1000 Recommendation

8. F Weller K, Groffik A, Church MK, et al.: Development and validation of the Urticaria Control Test: a patient-reported outcome instrument for assessing urticaria control. J Allergy Clin Immunol. 2014; 133(5): 1365-72, 1372.e1-6. PubMed Abstract | Publisher Full Text | F1000 Recommendation

9. $\quad F$ Baiardini I, Pasquali M, Braido F, et al:: A new tool to evaluate the impact of chronic urticaria on quality of life: chronic urticaria quality of life questionnaire (CU-QoL). Allergy. 2005; 60(8): 1073-1078. PubMed Abstract | Publisher Full Text | F1000 Recommendation

10. F Jariwala SP, Moday H, de Asis ML, et al.: The Urticaria Severity Score: a sensitive questionnaire/index for monitoring response to therapy in patients with chronic urticaria. Ann Allergy Asthma Immunol. 2009; 102(6): 475-482. PubMed Abstract | Publisher Full Text | F1000 Recommendation
11. Sussman G, Hébert J, Gulliver W, et al.: Insights and advances in chronic urticaria: a Canadian perspective. Allergy Asthma Clin Immunol. 2015; 11(1): 7. PubMed Abstract | Publisher Full Text | Free Full Text

12. F Staevska $M$, Gugutkova $M$, Lazarova $C$, et al:: Night-time sedating $\mathbf{H}_{1}$ antihistamine increases daytime somnolence but not treatment efficacy in chronic spontaneous urticaria: a randomized controlled trial. Br J Dermatol. chronic spontaneous

PubMed Abstract | Publisher Full Text | Free Full Text | F1000 Recommendation

13. F Fedorowicz Z, van Zuuren EJ, Hu N: Histamine H2-receptor antagonists for urticaria. Cochrane Database Syst Rev. 2012; 3: CD008596. PubMed Abstract | Publisher Full Text | F1000 Recommendation

14. Xolair® Omalizumab. Fda.gov. United States Food and Drug Administration. 2015 Reference Source

15. Chang TW, Chen C, Lin CJ, et al:: The potential pharmacologic mechanisms of omalizumab in patients with chronic spontaneous urticaria. $J$ Allergy Clin Immunol. 2015; 135(2): 337-342. Immunol. 2015; 135(2): 337-342.
PubMed Abstract | Publisher Full Text

16. Novartis Institutes for BioMedical Research: "Novartis Announces US FDA Approval of Xolair@ for Chronic Idiopathic Urticaria (CIU)." Novartis Media Relations, 2014 Relations, 2014.

17. Novartis.ca. Novartis Pharmaceuticals Canada Inc. "Novartis Announces That Xolair Is Approved in Canada as a Licensed Therapy for Chronic Idiopathic Urticaria (CIU) Patients Unresponsive to Antihistamines." 2014. Urticaria (CIU) Patien
Reference Source

18. $\mathrm{F}$ Maurer M, Rosén $\mathrm{K}, \mathrm{Hsieh} \mathrm{HJ}$, et al:: Omalizumab for the treatment of chronic idiopathic or spontaneous urticaria. N Engl J Med. 2013; 368(10): 924-935.

PubMed Abstract | Publisher Full Text | F1000 Recommendation

19. F Kaplan A, Ledford D, Ashby M, et al.: Omalizumab in patients with symptomatic chronic idiopathic/spontaneous urticaria despite standard combination therapy. J Allergy Clin Immunol. 2013; 132(1): 101-109. PubMed Abstract | Publisher Full Text | F1000 Recommendation

20. F Saini SS, Bindslev-Jensen C, Maurer M, et al.: Efficacy and safety of omalizumab in patients with chronic idiopathic/spontaneous urticaria who remain symptomatic on $\mathrm{H}_{\text {}}$ antihistamines: a randomized, placebo-controlled study. J Invest Dermatol. 2015; 135(1): 67-75.

PubMed Abstract | Publisher Full Text | Free Full Text | F1000 Recommendation 
21. Sussman G, Hébert J, Barron C, et al.: Real-life experiences with omalizumab for the treatment of chronic urticaria. Ann Allergy Asthma Immunol. 2014; 112(2): 170-174. PubMed Abstract | Publisher Full Text

22. F Metz M, Ohanyan T, Church MK, et al.: Omalizumab is an effective and rapidly acting therapy in difficult-to-treat chronic urticaria: a retrospective clinical analysis. J Dermatol Sci. 2014; 73(1): 57-62.

PubMed Abstract | Publisher Full Text | F1000 Recommendation
23. F Labrador-Horrillo M, Valero A, Velasco M, et al.: Efficacy of omalizumab in chronic spontaneous urticaria refractory to conventional therapy: analysis of 110 patients in real-life practice. Expert Opin Biol Ther. 2013; 13(9): 1225-1228. PubMed Abstract | Publisher Full Text | F1000 Recommendation

24. Maurer M, Church MK, Gonçalo M, et al.: Management and treatment of chronic urticaria (CU). J Eur Acad Dermatol Venereol. 2015; 29(Suppl 3): 16-32. PubMed Abstract | Publisher Full Text 


\section{Open Peer Review}

\section{Current Peer Review Status:}

\section{Editorial Note on the Review Process}

Faculty Reviews are review articles written by the prestigious Members of Faculty Opinions. The articles are commissioned and peer reviewed before publication to ensure that the final, published version is comprehensive and accessible. The reviewers who approved the final version are listed with their names and affiliations.

\section{The reviewers who approved this article are:}

\section{Version 1}

\section{Riccardo Asero (iD)}

Ambulatorio di Allergologia, Clinica San Carlo, Milan, Italy

Competing Interests: No competing interests were disclosed.

\section{Richard Warrington}

Department of Medicine \& Immunology, University of Manitoba, Winnipeg, MB, Canada

Competing Interests: No competing interests were disclosed.

The benefits of publishing with F1000Research:

- Your article is published within days, with no editorial bias

- You can publish traditional articles, null/negative results, case reports, data notes and more

- The peer review process is transparent and collaborative

- Your article is indexed in PubMed after passing peer review

- Dedicated customer support at every stage

For pre-submission enquiries, contact research@f1000.com 